\section{AS EXPERIÊNCIAS DE LAZER NA CIDADE: 0 COTIDIANO DA PRAÇA DE BOLSO DO CICLISTA DE CURITIBA, PARANÁ}

\author{
LEISURE EXPERIENCES IN THE CITY: THE DAILY LIFE OF PRAÇA DE BOLSO \\ DO CICLISTA IN CURITIBA, PARANÁ
}

\author{
EXPERIENCIAS DE OCIO EN LA CIUDAD: EL COTIDIANO DE LA PLAZA DE \\ BOLSILLO DEL CICLISTA DE CURITIBA, PARANÁ
}

\author{
Daniella Tschöke Santana*, Simone Rechia*, \\ Emília Amélia Pinto Costa Rodrigues**, Luize Moro***
}

Resumo: Microrrevolução coletiva e marco da cultura da bicicleta em Curitiba/PR, a Praça de Bolso do Ciclista (PBC) é um pequeno espaço público cujo processo de implementação revelou questões significativas para a vida na cidade. Objetivou-se descrever as formas de apropriação da PBC, com o olhar voltado para o cotidiano vivido após sua inauguração, tendo como base as experiências de lazer. Estudo de caso de abordagem qualitativa, utilizou-se de documentos, observações sistemáticas, registros fotográficos e entrevistas semiestruturadas como fontes de evidências. Percebeu-se que as formas de apropriação foram sendo modificadas após a inauguração da praça, espaço que abriga diversos usos e que, mesmo com todas as controvérsias decorrentes de uma apropriação rápida e intensa do local, tornou-se também um espaço de ação política e cidadã, pelo "ativismo gentil" (COOMBS, 2012) que promove, acomodando novas e diversas relações sociais, mas também ressaltando outras já existentes, a partir de atividades vivenciadas no lazer.

Keywords:

Urban Area.

Leisure Activities.

Common living and

Leisure Centers.

Abstract: As a collective micro-revolution and a landmark of bicycle culture in Curitiba, PR, Praça de Bolso do Ciclista (PBC), or Pocket Biker's Square, is a small public space whose implementation process revealed significant issues for life in that city. The purpose of this study was to describe the ways of appropriating PBC, focusing on the daily life experienced after its opening, based on leisure experiences. This is a qualitative case
Palabras clave: Área urbana. Actividades de Ocio. Centros de Ocio y Convivencia. study using documents, systematic observations, photographic records and semistructured interviews as sources of evidence. The forms of appropriation were gradually modified after the opening of the square - a space with several uses and which, even with all its controversies resulting from a fast and intense appropriation of the place, also became a space for political and civic action by 'gentle activism' (COOMBS, 2012) it promotes, accommodating new and diverse social relations but also highlighting existing ones based on activities experienced in leisure.

Resumen: Microrrevolución colectiva y marco de la cultura de la bicicleta en Curitiba/PR, la Plaza de Bolsillo del Ciclista (PBC) es un pequeño espacio público cuyo proceso de implementación reveló cuestiones significativas para la vida en la ciudad. El objetivo ha sido describir las formas de apropiación de la PBC, con la mirada puesta en el cotidiano vivido después de su inauguración, teniendo como base las experiencias de ocio. Estudio de caso de abordaje cualitativo, utilizó documentos, observaciones sistemáticas, registros fotográficos y entrevistas semiestructuradas como fuentes. Se percibió que las formas de apropiación se fueron modificando después de la inauguración de la plaza, espacio da abrigo a diversos usos y que, pese a todas las controversias derivadas de una apropiación rápida e intensa del local, se convirtió también en un espacio de acción política y ciudadana por el "activismo gentil" (COOMBS, 2012) que promueve, acomodando nuevas y diversas relaciones sociales, pero también resaltando también otras ya existentes, a partir de actividades vividas en el ocio.
*Universidade Federal do Paraná (UFPR). Curitiba, PR, Brasil. E-mail: dani_ellats@hotmail.com; simone@ufpr.br

**Universidade Federal da Bahia (UFBA). Salvador, BA, Brasil. E-mail: milapcosta@ hotmail.com

${ }^{* * *}$ Centro Universitário Autônomo do Brasil (UniBrasil). Curitiba, PR, Brasil. E-mail: luize.moro@yahoo.com.br

Recebido em: 23-11-2018 Aprovado em: 19-06-2019 Publicado em: 18-12-2019

DOI: hitps://doi.org/10.22456/1982-8918.88373

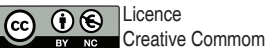




\section{INTRODUÇÃO}

O espaço modifica-se para atender às transformações da sociedade e pelo movimento geral da sociedade também se pode apreender o movimento geral do espaço (SANTOS, 2012b). Os diferentes marcos temporais e contextos estabelecem distintas regras e alteram as formas pelas quais se concebe o espaço e suas possibilidades de produção. Para Souza (2013), frente às formas atuais das cidades, a organização espacial não vem sendo apenas alterada, mas constantemente desafiada:

[...] a cada 'ordem' socioespacial aparecerá, mais cedo ou mais tarde, ao menos em uma sociedade injusta e heterônoma, um contraprojeto (ou vários contraprojetos concorrentes) que proporá ou pressuporá, explícita ou implicitamente, novas estruturas socioespaciais, para agasalhar novas relações sociais. A implosão ou corrosão de uma 'ordem', gerando em certos observadores a impressão de um estado de 'desordem', pode ser vista com pessimismo ou otimismo, dependendo dos interesses, do papel social e, por conseguinte, da perspectiva ou visão de mundo (SOUZA, 2013, p. 38).

Esses contraprojetos podem emergir na tentativa de alterar o modo como a vida social está condicionada, buscando atender a necessidades imediatas, prioridades da sociedade de cada tempo, constituindo, segundo Rechia (2015, p. 45 apud Harvey (1989¹), um direito à cidade, que significa mais do que ter acesso aos recursos que a cidade oferece, "[...] é o direito de reinventar ou até mesmo mudar a cidade a partir de aspirações e desejos, o que depende do exercício coletivo do poder sobre os processos de urbanização".

Considerando que a "[...] reflexão sobre a prática socioespacial, ou seja, o modo pelo qual se realiza a vida na cidade, está centrada na relação dialética entre os espaços construídos e suas formas de apropriação" (RECHIA, 2015, p. 47-48), este artigo analisa as formas de apropriação da Praça de Bolso do Ciclista da cidade de Curitiba/PR, com o olhar voltado para o cotidiano após sua inauguração, tendo como base as experiências vividas no tempo/espaço de lazer.

Segundo Morente (2018), a apropriação faria mais habitável uma cidade e, retomando ideias de Lefebvre, afirma que:

Apropiarse es sublimar la existencia, regresar a la vida cotidiana plena y devolver a lo urbano lo que nunca debió de perder, el deseo y el desequilibro, lo lúdico y lo imprevisible (Lefebvre, 1973); tan pronto apropiamos, esculpimos nuestro mundo (Lefebvre, 1978) (MORENTE, 2018, p. 9).

Uma relação de confiança e apreensão do espaço, pelo olhar ou conviver, influencia o processo de apropriação, que "[...] constituiu um dos processos fundamentais da relação pessoa-ambiente e da formação de lugares, que são a marca da natureza humana no espaço" (CAVALCANTE; ELIAS, 2011, p. 63). Para esses autores, a apropriação pode acontecer pela esfera da ação/transformação do espaço, consistindo em comportamentos explícitos (demarcação, ocupação territorial, atitudes de reivindicação, delimitação e defesa), e também pela identificação simbólica, relacionada a processos afetivos, interativos, que configuram ao espaço reconhecimento, significação, para um sujeito ou grupo social. Com predomínio de um sobre outro, esses processos geralmente configuram-se complementares. 
Santos e Vogel $^{2}$ (1985 apud MENDONÇA, 2007, p. 297) atribuem às apropriações dos espaços públicos a função de "[...] mecanismos de defesa e superação da população aos modelos urbanísticos impostos pelos planejadores". Solà-Morales (1995, p. 27, tradução nossa) indica que os terrenos vazios podem aparecer como uma "contra-imagem da cidade, seja no sentido de uma crítica sua, seja no sentido do indício de sua possível superação". O habitante da metrópole percebe os espaços fora das estruturas produtivas das cidades, ou não dominados pela arquitetura, com dupla condição: enquanto reflexo da sua própria insegurança, mas também como uma possibilidade para a alternativa, o utópico e o futuro (SOLÀ-MORALES, 1995).

Sendo assim, se "[...] la zonificación y la privatización son la caricatura del movimiento moderno (Gehl, 2011) y la normativización social el modo de regular la creatividad desviada de la ciudadanía (Davis, 1990; Margier, 2017)" (MORENTE, 2018, p. 8), percebe-se a importância de apreender o que ocorre nos espaços públicos da cidade, enquanto espaços representativos que maximizam as possibilidades de mistura funcional e social na cidade (MORENTE, 2018).

\section{METODOLOGIA}

Consideramos este um estudo de caso qualitativo, o qual, segundo Yin (2001),

[...] é uma investigação empírica que investiga um fenômeno contemporâneo dentro de seu contexto da vida real, especialmente quando os limites entre o fenômeno e 0 contexto não estão claramente definidos. [...] baseia-se em várias fontes de evidências, com os dados precisando convergir em um formato de triângulo, e, como outro resultado, beneficia-se do desenvolvimento prévio de proposições teóricas para conduzir a coleta e a análise de dados (YIN, 2001, p. 32-33).

Algumas fontes de evidência foram os recursos utilizados para a investigação: documentos (on-line, oficiais), roteiro de observação (13 observações de março a dezembro de 2015, duração média de duas horas cada, em três períodos do dia - úteis e fins de semana), registros de imagem e roteiro de entrevistas semiestruturadas. Foram entrevistadas 24 pessoas, de ambos os sexos e com mais de 18 anos de idade (organizadas por diferentes categorias: frequentadores da praça, donos de estabelecimentos/moradores do entorno, integrantes da associação de ciclistas, voluntários e gestores municipais). Antes da entrevista, todos os participantes receberam e assinaram um Termo de Consentimento Livre e Esclarecido.

Os dados foram sistematizados e triangulados e, para assegurar a fidedignidade da análise, foram considerados alguns cuidados propostos por Minayo (2012):

(3) a triangulação interna à própria abordagem, que consiste em olhar o objeto sob seus diversos ângulos, comparar os resultados de duas ou mais técnicas de coleta de dados e de duas ou mais fontes de informação, por exemplo. (4) A validação dos relatos, comparando as falas com as observações de campo. (5) 0 alerta para os relatos e os fatos que contradigam as propostas e as hipóteses do investigador, tratando de problematizá-los e de apresentá-los, em lugar de ocultá-los (MINAYO, 2012, p. 625).

2 SANTOS, Carlos Nelson F. dos; VOGUEL, Arno. Quando a Rua Vira Casa: a apropriação dos espaços de uso coletivo em um centro de bairro. 3. ed. São Paulo: IBAM, 1985. 
Elaborou-se uma análise interpretativa, a qual "nunca será a última palavra sobre 0 objeto estudado" (MINAYO, 2012, p. 625), pois o sentido de uma mensagem ou realidade está aberto em várias direções, mas a interpretação, quando bem conduzida, pode ser fiel ao campo.

Estudo aprovado pelo Comitê de Ética em Pesquisa da Saúde da Universidade Federal do Paraná, sob o número de registro CAAE 48211015.2.0000.0102, conforme a resolução no 466/12 do Conselho Nacional de Saúde (BRASIL, 2013).

\section{REVISITANDO A PRAÇA DE BOLSO DO CICLISTA DE CURITIBA/PR}

De forma breve, revisitamos o processo de implementação da PBC. A PBC está situada na região central de Curitiba, na esquina das ruas Presidente Faria e São Francisco, sendo esta última de relevância histórica por ser uma das ruas mais antigas da cidade, onde notam-se prédios e calçamentos característicos do século XIX3. Está cercada de pontos de interesse da cidade ${ }^{4}$, tais como a Catedral Basílica Nossa Senhora da Luz dos Pinhais (270 m), o Passeio Público (350 m), o Teatro Guaíra (500 m), a Praça Santos Andrade (210 m - onde em frente há um campus da Universidade Federal do Paraná) e a Rua XV de Novembro (rua pedestrianizada, principalmente comercial) (SANTANA, 2016) (Figura 1).

Figura 1 - Praça de Bolso do Ciclista - pontos de interesse de Curitiba/PR

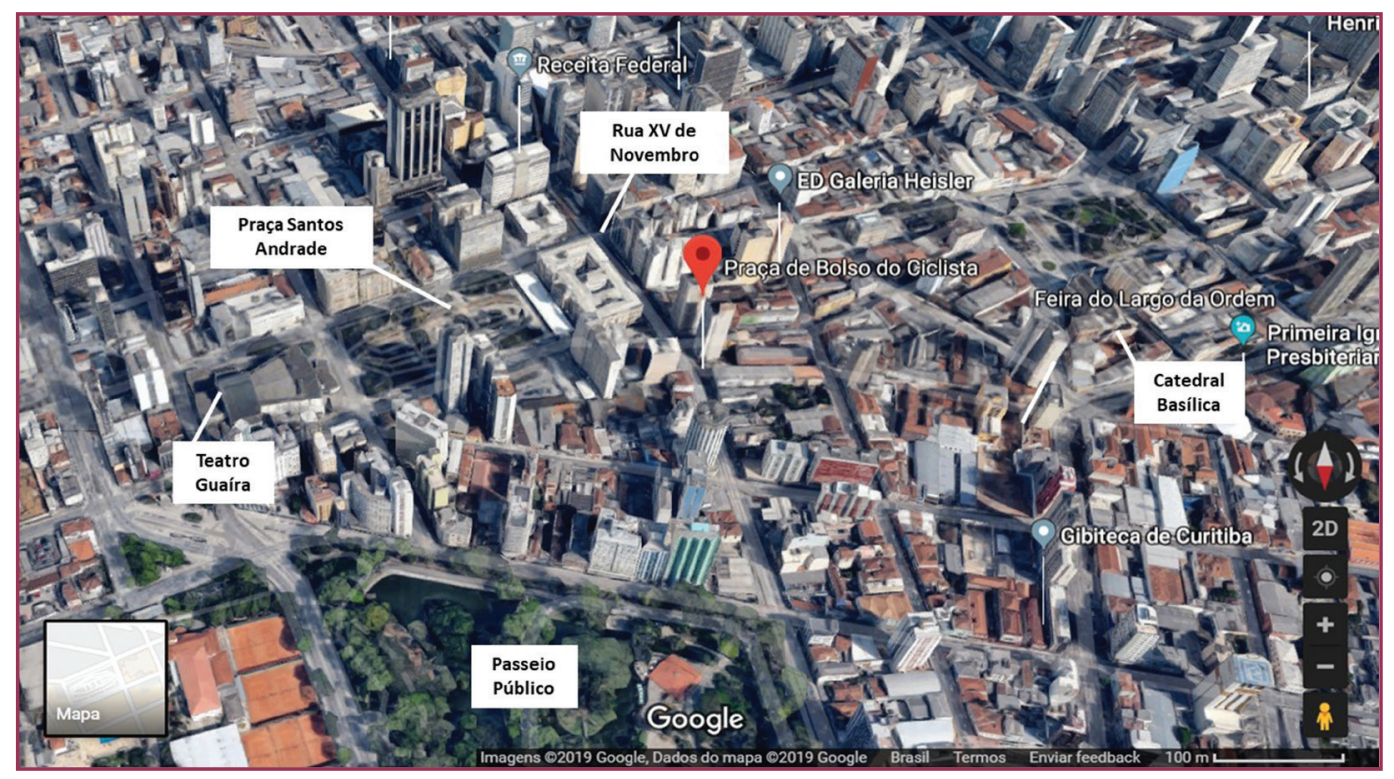

Fonte: Google Maps - www.bit.ly/pbc_curitiba

Fruto de microrrevolução coletiva e marco da cultura da bicicleta em Curitiba (SANTANA, RECHIA, RODRIGUES, 2017), a PBC é um espaço público de $127 \mathrm{~m}^{2}$, construído por meio de "mutirões", iniciativa principalmente de cicloativistas, com apoio da comunidade, em parceria com a Prefeitura Municipal.

3 Em 2012, ações de revitalização aconteceram na rua São Francisco (pintura dos prédios, alargamentos das calçadas, nivelamento do paralelepípedo, melhorias na iluminação, etc.), visando ampliar o comércio e aumentar a circulação de pessoas na região.

4 Distâncias considerando trajetos realizados a pé. 
Em 2011, dois grupos envolvidos com o uso da bicicleta na cidade ${ }^{5}$ perceberam o terreno vazio e subutilizado ${ }^{6}$ em frente à sua sede e solicitaram a construção da praça à Prefeitura, que respondeu positivamente. No entanto, os encaminhamentos da proposta acabaram em segundo plano na agenda municipal de planejamento. Cicloativistas e comunidade interessada propuseram então a construção coletiva do local. A municipalidade autorizou o processo, cedeu o espaço, realizou ajustes iniciais no terreno e disponibilizou alguns materiais de depósitos de secretarias municipais. Uma construtora particular com empreendimentos na região também contribuiu com materiais e recursos financeiros.

As ações dos mutirões (planejamento, organização e construção) estavam abertas aos interessados em participar e aconteceram principalmente nos finais de semana, de maio a setembro de 2014. Lideranças voluntárias, que formaram um núcleo regular de 20 pessoas, aproximadamente, conduziram autonomamente as ações, a partir de suas experiências em diferentes áreas de atuação, ensinando os demais voluntários que chegavam. A rua São Francisco, próxima ao terreno, foi bloqueada para os automóveis, o que contribuiu para a circulação das pessoas no local, agregando outras também a partir da realização simultânea de atividades culturais (música, grafite, oficinas, teatro, dança, jogos, brincadeiras infantis), além de ações para conscientização do uso da bicicleta na cidade. 0 espaço foi inaugurado em 22/09/2014, ocasião do Dia Mundial sem Carro. Sua estrutura traz marcas características da cidade, como o chão de petitpavet (ou pedra portuguesa), e de sustentabilidade, como o concregrama e banco de superadobe ${ }^{7}$, além de mobiliários como paraciclos, bancos de madeira, muretas de pedra, minipalco e tela de projeção ao ar livre (Figura 2).

Figura 2 - Praça de Bolso do Ciclista (PBC)

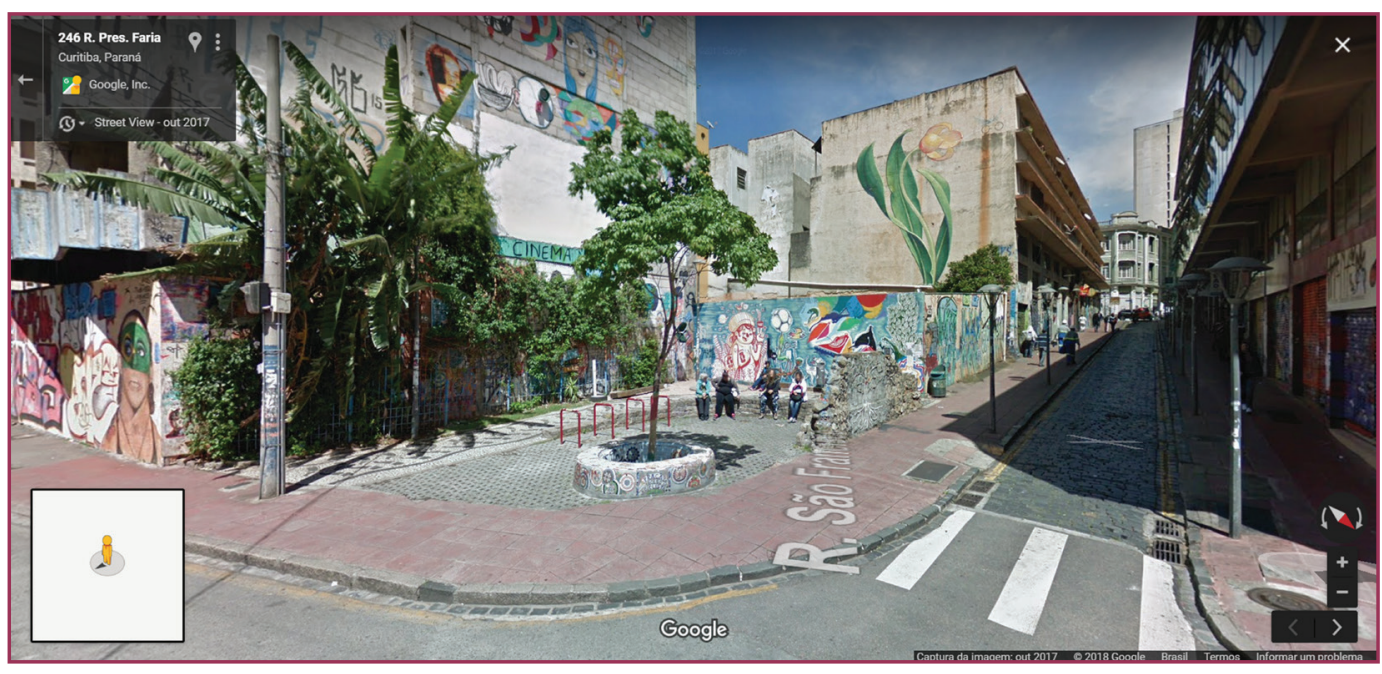

Fonte: Google Maps Street View (2018)

A condução, os temas articulados e o próprio processo de construção da praça desenvolveram, nas palavras de Certeau (2014, p. 41), algumas '[...] 'maneiras de fazer'

\footnotetext{
5 (1) a Ciclolguaçu, Associação de Ciclistas do Alto Iguaçu, criada em 2011 "com um intuito bem definido - criar uma interface de diálogo construtivo com o poder público a fim de consolidar o desenvolvimento de políticas de ciclomobilidade" (CICLOIGUAÇU, 2017); (2) a Bicicletaria Cultural, um empreendimento privado de apoio ao ciclista urbano, "[...] uma estratégia para o cultivo de um corpo social unindo mobilidade e arte como base para ações culturais, fornecendo também apoio aos ciclistas com sua oficina e seu exclusivo estacionamento de bicicletas, tornando-a um negócio social" (INSTITUTO LEGADO, 2018).

6 Um remanescente urbano que, quando considerado seu valor de troca (LEFEBVRE, 2001), pode ser considerado improdutivo financeiramente em uma região da cidade onde, paradoxalmente, o $\mathrm{m}^{2}$ tende a custar em média R\$ 6.700,00 (IMOVELWEB, 2019). Uma porção é de propriedade da prefeitura municipal e outra faz parte uma massa falida contígua (SANTANA, RECHIA, RODRIGUES, 2017). A PBC foi construída apenas na porção pública do terreno.

7 Método de bioconstrução (terra comprimida em sacos para criar estruturas).
} 
[que] constituem as mil práticas pelas quais usuários se reapropriam do espaço organizado pelas técnicas da produção sociocultural". A análise dessas operações "quase microbianas" insurgentes no seio das "estruturas tecnocráticas" coloca em evidência a importância de identificar estas brechas do cotidiano, as quais podem refletir movimentos que podem modificar a organização de um espaço, desafiando lógicas consolidadas. A próxima seção tem o objetivo de relatar como ocorreu o movimento de apropriação deste espaço, evidenciando o cotidiano do lugar vivido após sua implementação.

\section{LUGAR VIVIDO: AS FORMAS DE APROPRIAÇÃO DA PRAÇA DE BOLSO DO CICLISTA}

Após sua inauguração, buscou-se observar as experiências de lazer, as formas de apropriação da PBC. Diferentes períodos do dia ou dias úteis e finais de semana mostraram formas díspares de uso do espaço da praça e seu entorno (principalmente a rua São Francisco). Considerando o período das observações, verificou-se que nos dias úteis, especialmente de manhã, a principal função da praça era passagem de pedestres (Figura 3), que faziam conexão entre as ruas Presidente Faria e São Francisco. Outras atividades consistiam em sentar nos bancos, geralmente para conversar, fumar, escutar música com fones de ouvido e manusear 0 celular (Figura 4). De modo geral, as pessoas permaneciam por pouco tempo na praça, entre dois e cinco minutos e estavam sozinhas ou acompanhadas em grupos de três a sete pessoas aproximadamente. Entre 10h e 10h30, principalmente nas observações de julho a novembro, a quantidade de pessoas na praça aumentava, sendo registradas até 30 pessoas ao mesmo tempo na praça neste horário. Eram em sua maioria jovens, que portavam bolsas ou mochilas e este fato pode estar conectado com o horário do intervalo das aulas da escola localizada na rua São Francisco.

Figura 3 - Pedestres na PBC - dia de semana/manhã

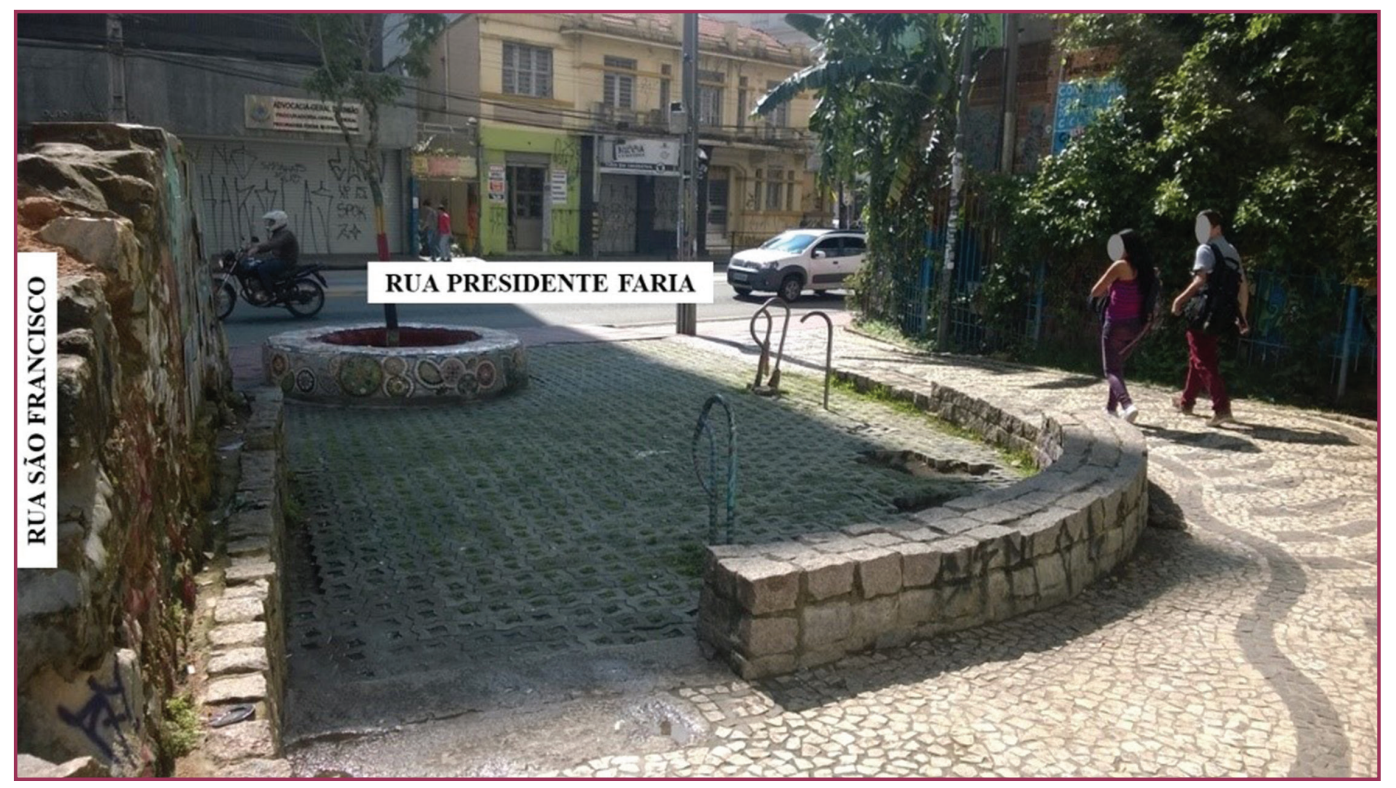

Fonte: Arquivo pessoal (2015) 
Figura 4 - PBC - dia de semana/manhã

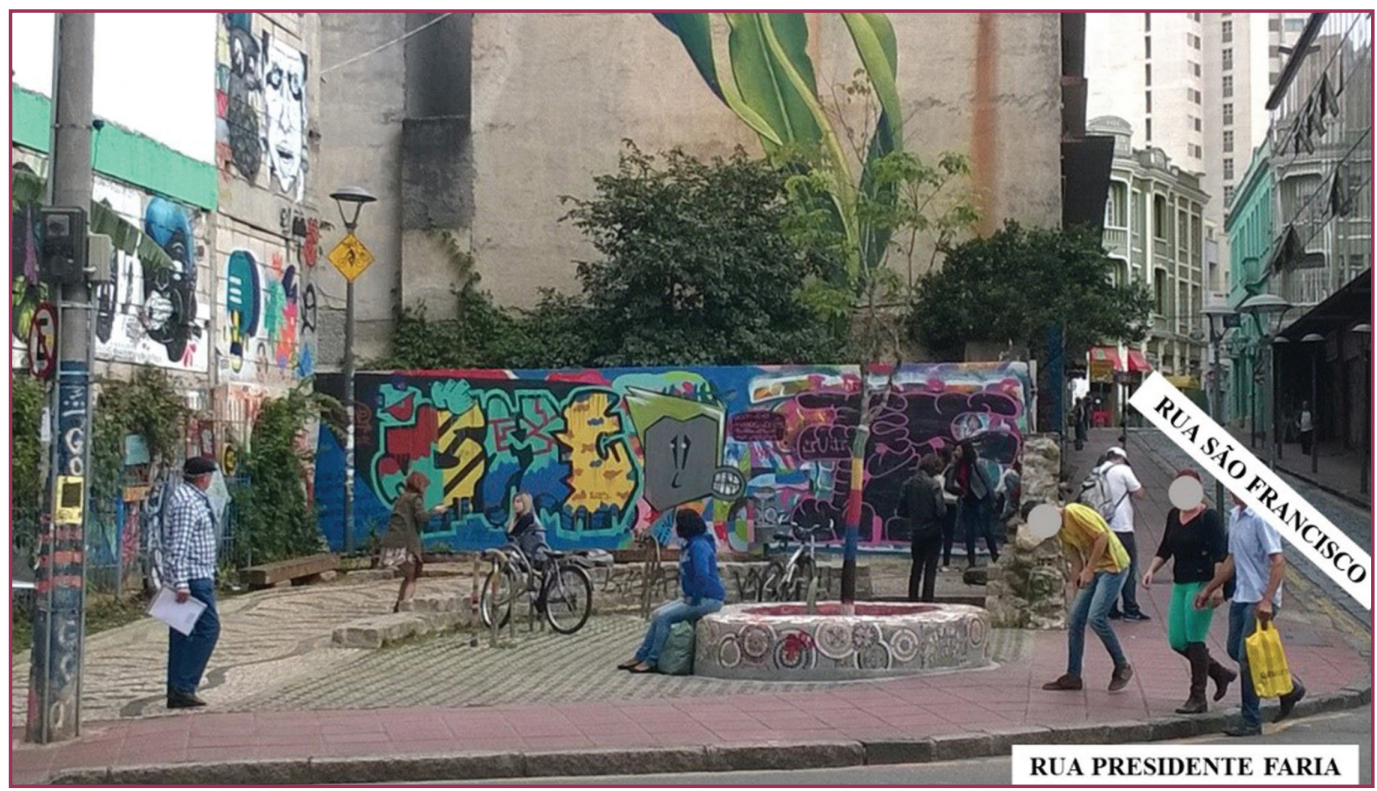

Fonte: Arquivo pessoal (2015)

À tarde em dias úteis, o fluxo, a quantidade de pessoas e o tempo de permanência, tanto na praça quanto nas calçadas da primeira quadra da rua São Francisco, aumentavam quando comparados ao período da manhã. As atividades observadas eram semelhantes às já identificadas, somadas ao consumo de bebidas. Jovens cantando e tocando violão foram vistos em algumas ocasiões. A partir da metade da tarde a quantidade de pessoas na praça aumentava ainda mais, consistindo principalmente de público jovem, cujas atividades permaneciam as referidas (conversar, fumar, escutar música com fones de ouvido e manusear o celular).

Em ambos os períodos, manhã e tarde, havia uma movimentação tímida de bicicletas, sendo estas muitas vezes bicicletas utilizadas como meio de locomoção de prestadores de serviços (Figura 5).

Figura 5 - Bicicleta de serviço na PBC - dia de semana/tarde

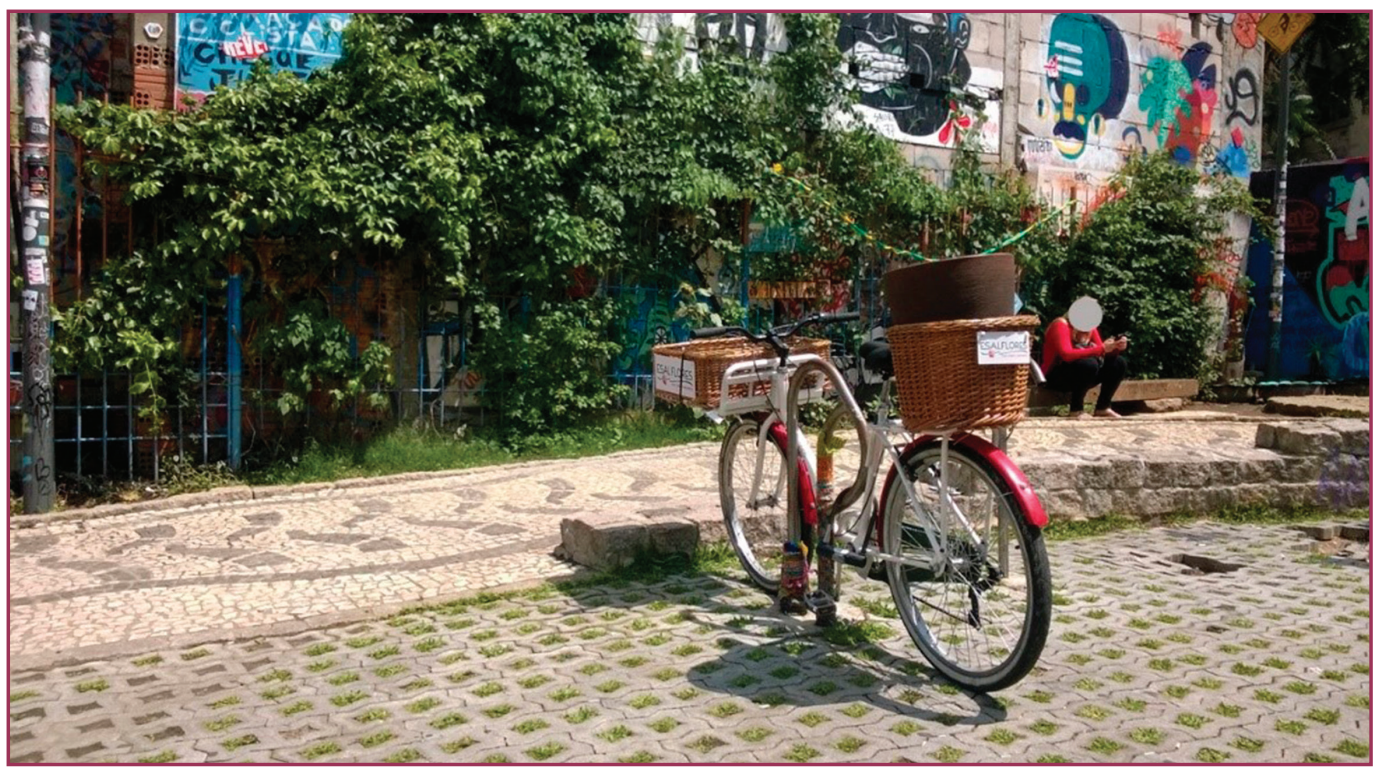

Fonte: Arquivo pessoal (2015) 
No final da tarde e no período da noite, principalmente de quinta-feira a domingo, uma quantidade superior de pessoas começava a ser vista no local em comparação aos demais períodos. Ao anoitecer, a primeira quadra da rua São Francisco, por ser estreita, fechavase informalmente, uma vez que as calçadas e a própria praça não comportavam o número de pessoas que ali se reuniam e por isso ocupavam a rua (Figuras 6 e 7). Os carros se direcionavam na tentativa de circular pela rua São Francisco, mas dificilmente obtinham êxito. Alguns poucos motoristas se arriscavam a atravessar a aglomeração das pessoas, que muito lentamente abriam espaço para a passagem do veículo.

Via-se que as pessoas se reuniam em grupos variados, alguns de três e quatro pessoas, outros de oito a dez pessoas, que conversavam, fumavam, ingeriam bebidas, tocavam ou escutavam música. Verificou-se que o tempo de permanência das pessoas era de 20-30 minutos até 1 hora ou mais, tempo maior em relação aos outros dois períodos do dia. Quando um grupo "liberava" um espaço da praça, este ficava por pouco tempo vazio, pois outro conjunto de pessoas já ocupava o lugar.

À noite percebeu-se haver mais bicicletas ao longo da rua São Francisco e da praça, no entanto, poucas estacionavam nos paraciclos, geralmente permaneciam junto aos próprios ciclistas ou presas à grade da lateral esquerda da praça, onde fica a jardinagem. Os paraciclos localizam-se no centro da praça, e como existe uma grande ocupação à noite, notou-se que parar a bicicleta nas laterais é uma forma de "economizar" espaço, deixando o centro livre para maior circulação.

Em relação aos finais de semana, a ocupação durante a manhã e tarde se mostrou um pouco maior quando comparada aos dias úteis, com a presença de turistas e curiosos em conhecer o local, no entanto, só tinha aumento expressivo quando algum evento era sediado na praça ou na rua São Francisco. À noite a movimentação era semelhante aos dias de semana, com um fluxo ainda maior de pessoas.

Figura 6 - Ocupação da Rua São Francisco - dia de semana/noite

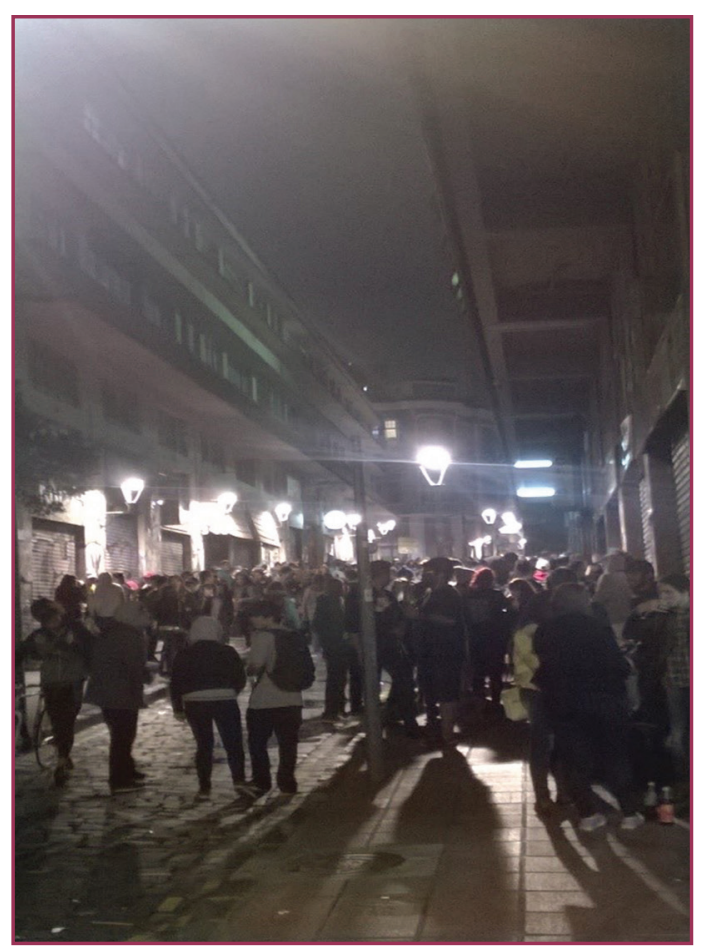

Fonte: Arquivo pessoal (2015) 
Figura 7 - Ocupação da PBC - dia de semana/noite

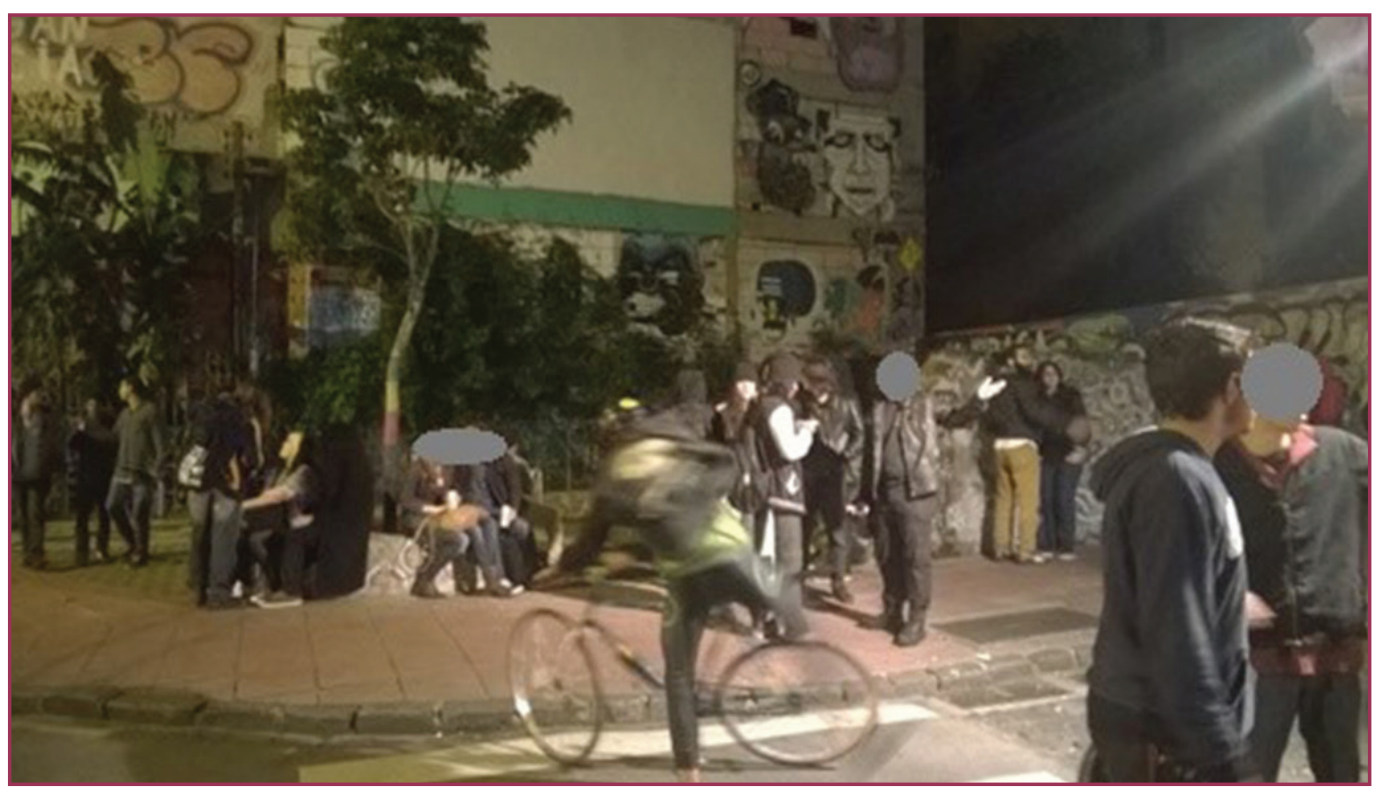

Fonte: Arquivo pessoal (2015)

Eventos e atividades culturais (passeios ciclísticos, exibição de documentários, míni shows, apresentações de dança e teatro) também aconteciam com regularidade na praça, não apenas relacionados à bicicleta, mas também ao contexto vivido no momento na cidade. A realização de um evento de migrantes haitianos ("Somos todos migrantes"), como forma de mostrar sua cultura e chamar atenção para o crescimento desta população na cidade, e um ciclo de debates, tematizando espaço público e participação política (com exibição do documentário Cidadania no concreto) são alguns exemplos. Passeios ciclísticos temáticos, Bicicletadas ${ }^{8} \mathrm{e}$ outros eventos relacionados à bicicleta veem na PBC um ponto de partida, constituindo espaço de educação e protestos, reivindicando segurança, respeito e infraestrutura adequada para os ciclistas na cidade (Figuras 8 e 9). A única atividade permanente que ocorria na praça era a Feira de Orgânicos, todas as quintas-feiras das 7 h30 às 15h (Figura 10).

Estima-se que as ações neste sentido ocorridas na PBC se aproximam da perspectiva que Coombs (2012) aponta, da existência de um "ativismo gentil", no qual o convite à ação e à participação da população em intervenções urbanas difere dos conceitos ativistas convencionais em favor de atividades divertidas, que geram aderência, mas ainda carregam uma mensagem a ser disseminada, revigorando os espaços públicos e dando vida a modos interativos e criativos de engajamento cívico (COOMBS, 2012).

Para Coombs, referindo-se especificamente à iniciativa do Park(ing) Day ${ }^{9}$, estas intervenções urbanas:

[...] podem colapsar as fronteiras entre a arte e a vida e usar experiências do dia a dia para oferecer novas concepções sobre o que este 'ativismo gentil' pode provocar no público participante. Elas aumentam a conscientização sobre as questões locais e, ao mesmo tempo, buscam ajudar os cidadãos a imaginar

8 A Bicicletada "[...] é uma iniciativa civil livre e horizontal, que busca promover os meios de transporte não motorizados e a cidadania" (BICICLETADA CURITIBA, 2018), pela reunião de indivíduos que ocupam a rua para se deslocarem juntos pela cidade. Movimento internacional, comumente chamado de "Massa Crítica", ocorre tradicionalmente na última sexta-feira do mês.

9 O Park(ing) day é um evento anual internacional no qual pessoas transformam vagas de estacionamento em espaços sociais interativos, parques públicos temporários. A primeira iniciativa ocorreu em 2005 em São Francisco (Estados Unidos) e tinha como objetivo chamar atenção para a falta de espaços verdes no centro da cidade. Atualmente é um movimento global que acontece toda terceira sexta-feira de setembro (COOMBS, 2012). 
maneiras diferentes de negociar ou confrontar essas questões por meio de uma interseção entre o design urbano e o ativismo baseado na comunidade (COOMBS, 2012, p. 64, tradução nossa).

Ainserção no espaço público permite reorganizar os aspectos do seu uso, reivindicando-o para gerar impactos sociais e políticos, com novas formas culturais de encorajar pessoas, instituições e comunidades a transformarem seu ambiente urbano e expandir as possibilidades culturais e de experiências a partir das práticas coletivas de todos os participantes (COOMBS, 2012).

Figura 8 - Ato na PBC reivindicando mais segurança - fim de semana/manhã

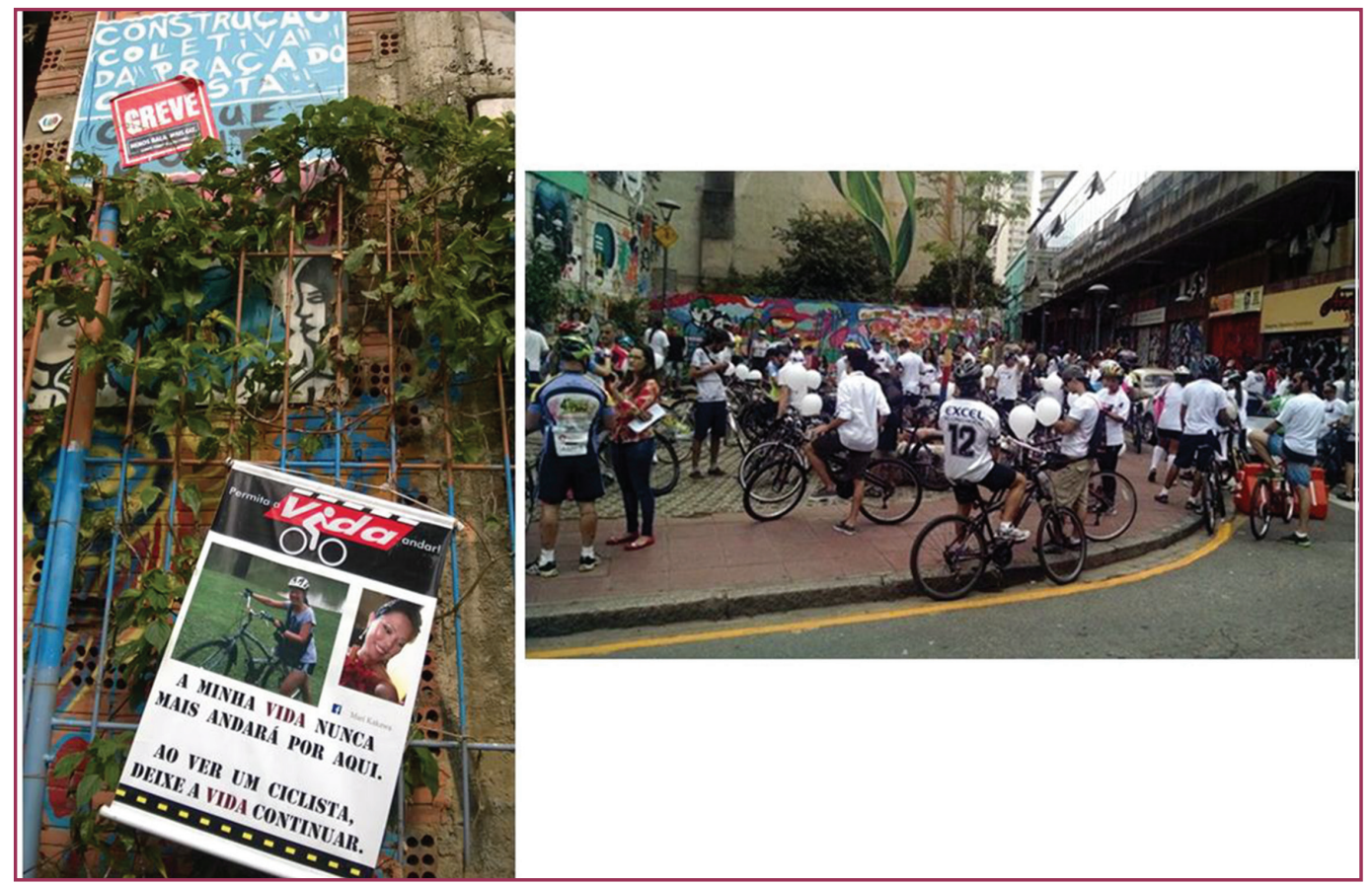

Fonte: Arquivo pessoal (2015) / Nascimento (2015)

Figura 9 - Exibição de documentário organizada pela Fundação Cultural de Curitiba na PBC - dia de semana/ noite

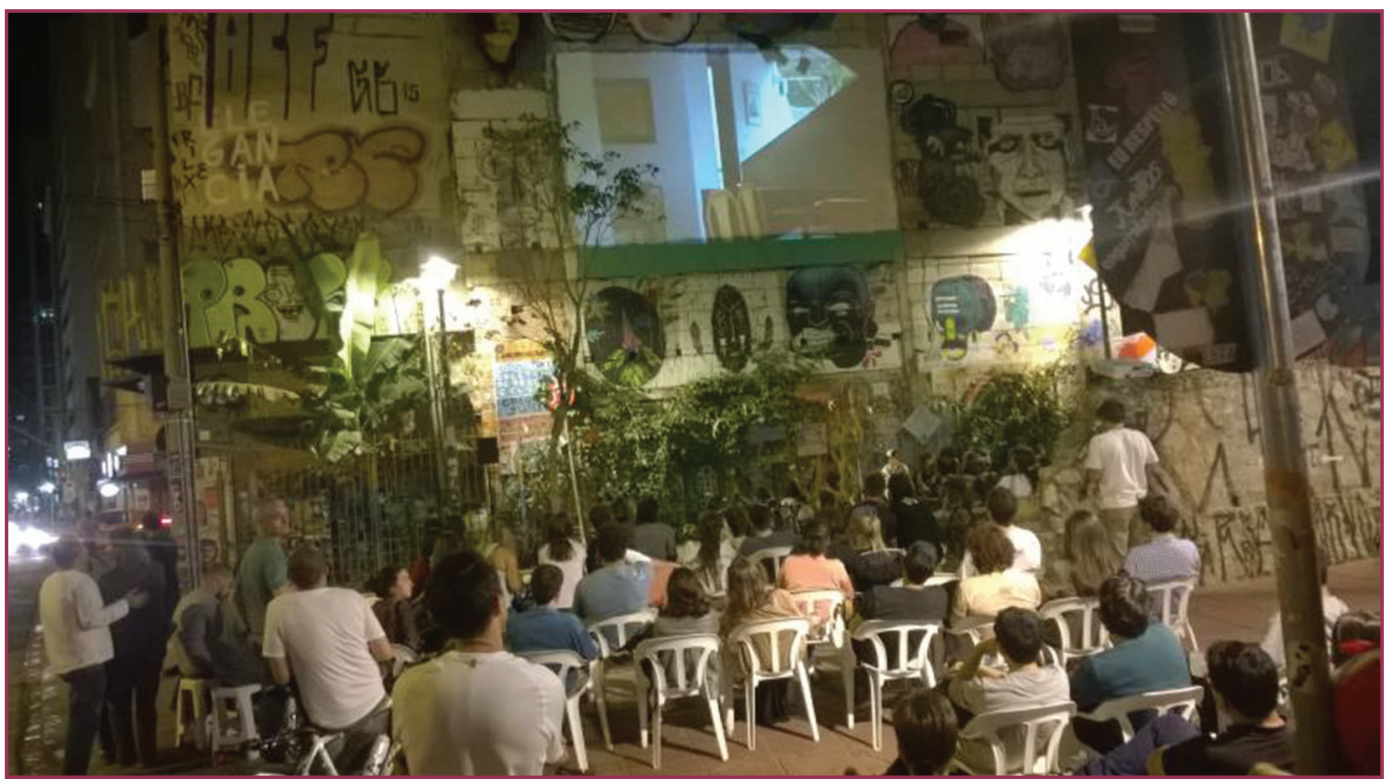

Fonte: Arquivo pessoal (2015) 
Figura 10 - Feira de Orgânicos na PBC - dia de semana/manhã

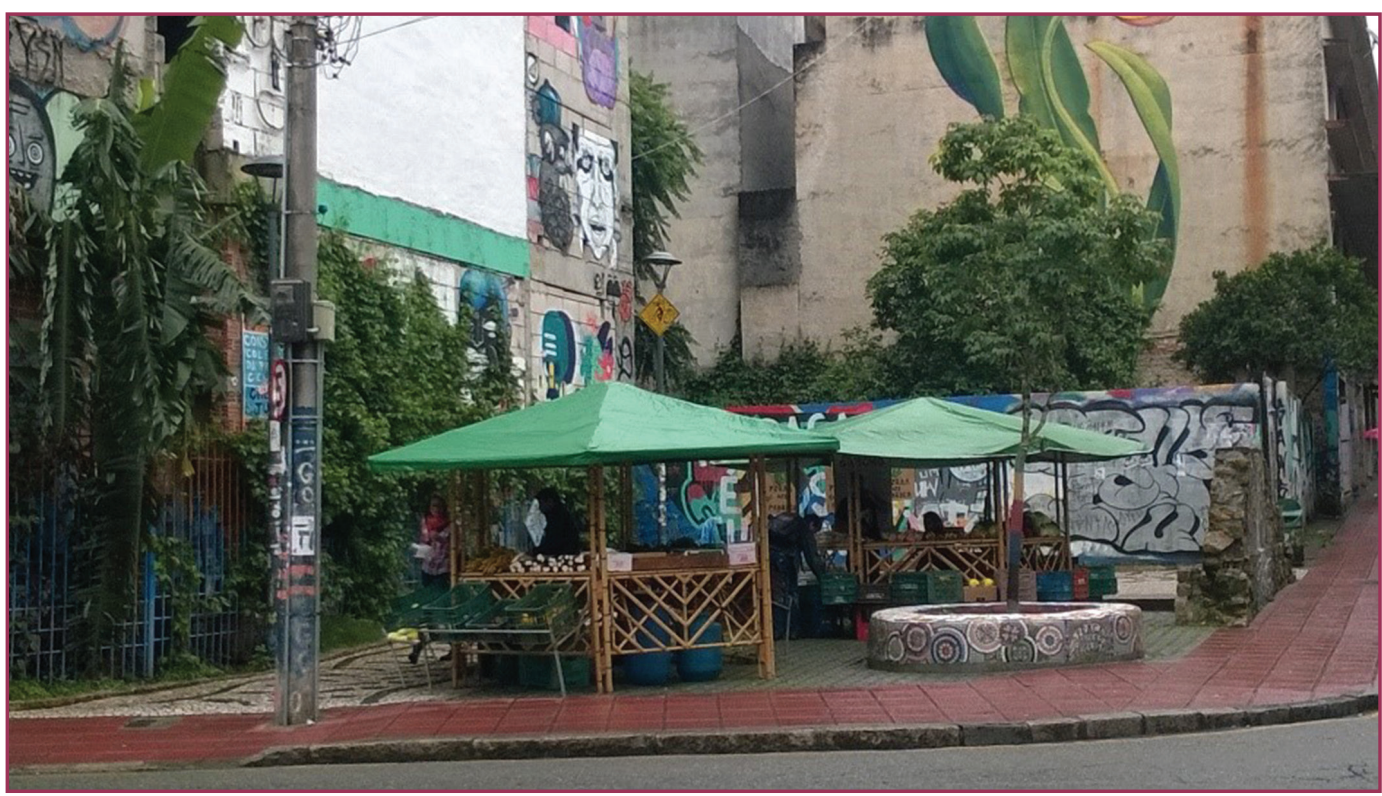

Fonte: Arquivo pessoal (2015)

Corroborando as observações realizadas, uma matéria sobre a rua São Francisco cita a PBC e seu cotidiano reforça algumas formas já identificadas de apropriação, e ao mesmo tempo aponta para as contradições que se intensificavam:

A Rua São Francisco amanhece preguiçosa. Enquanto uns poucos passantes vão ao trabalho, três ou quatro estabelecimentos abrem as portas. De quando em quando, um ou outro aluno vai até a Praça de Bolso do Ciclista para fumar um cigarro.

A via começa a acordar, de fato, perto do almoço, quando os restaurantes se aprontam para receber os clientes. É neste momento que parece guardar nuances do projeto de se tornar um polo gastronômico. 'A São Francisco se desenvolveu em torno deste conceito. No almoço ainda mantemos o mesmo volume de clientes. À noite, o movimento teve queda de 50\%, por causa dessa ocupação desordenada', diz [nome suprimido para evitar identificação].

À tarde, na Praça de Bolso, alguns jovens já se reúnem. Tocam e cantam. Entre eles, um grupo de argentinos e um estudante chileno. Ao fundo, outro grupo conversa e fuma. Cicloativistas - que idealizaram o espaço - também estão por ali. Mesmo à tarde, a Guarda Municipal e a PM não dão trégua. 'Se a gente vier dez vezes, em dez a gente encontra alguém com droga', diz [nome suprimido para evitar identificação] (ANÍBAL; ANDRADE, 2015).

Algumas tensões passam a permear a apropriação da região a partir de uma ocupação principalmente noturna espontânea e inesperada da praça e suas imediações, causando transtornos à comunidade local. Comerciantes e moradores, que inicialmente apoiavam a iniciativa, entendem que vem havendo um desrespeito dos usuários quando estes realizam práticas ilícitas, como consumir drogas próximo aos estabelecimentos e residências, quando as atitudes passam do limite da convivência harmoniosa no espaço público (brigas, algazarras, som alto) ou ainda quando há a depredação do espaço público (destruição de mobiliário postes, lixeiras, paraciclos - e presença de lixo e dejetos). Segundo donos de estabelecimento e moradores do entorno 
Só pra você ter uma ideia, o morador aqui, esse que mora lá no canto, essa semana eu estava lá à noite e, era mais de dez horas da noite, estava uma batucada ali, a gente não conseguiu nem conversar (DONO DE ESTABELECIMENTO/ MORADOR 8).

Então, no começo, há um ano e pouco atrás, dava seis horas da tarde, sete horas da tarde, colocavam um telão ali, um microfone e as pessoas com música e tal sem se preocupar com a escola, sempre foi assim. Daí começou os embates entre a escola e as pessoas que frequentavam a praça, principalmente os organizadores dos eventos da praça (DONO DE ESTABELECIMENTO/MORADOR 10).

Outra publicação aborda essas questões e mostra que a ocupação e o alto consumo de álcool e drogas são notáveis, geram polêmica e dispararam um sinal de alerta:

Longe de ser unanimidade, a Rua São Francisco expõe sua face mais agitada nas noites de sexta. É o período em que a via pulsa, tomada por uma vasta gama de 'tribos'. Entre garrafas, cigarros e acordes, elas tomam os cem metros da Praça de Bolso do Ciclista à Rua Riachuelo. Essa ocupação espontânea, no entanto, começa a preocupar a prefeitura, as forças de segurança e os comerciantes. As avaliações convergem em dois pontos: a aglomeração fugiu ao controle, o que ameaça o projeto inicial de tornar o local um polo gastronômico e cultural. [...] Por detrás dela, vieram ações policiais e da Guarda Municipal [...]

Nenhuma das esferas - poder público, vizinhos, empresários e comunidade escolar - parece saber lidar bem com o fenômeno. 0 que mais Ihes incomoda é a banalização do uso da maconha. 'Eles [os frequentadores] agem como se as drogas estivessem liberadas na rua', resume [nome suprimido para evitar identificação], para jovens e adultos. [...]

Obviamente, o consumo de maconha não é generalizado. A reportagem conversou com muitos frequentadores que vão à rua para fazer um happy hour, encontrar amigos e tomar uma cerveja ao ar livre. Ao mesmo tempo, alguns jovens preparam os cigarros, fumam e falam com tranquilidade sobre o uso e a repressão. [...] (ANÍBAL; ANDRADE, 2015b).

A rua São Francisco costumava ser uma rua pouco movimentada, com pouca circulação, abrigando atividades constantes de consumo e tráfico de drogas. Em 2012, passou por um processo de revitalização, como parte do "Projeto Novo Centro"10, que buscava transformála em um polo gastronômico e também, implicitamente, coibir o tráfico na região. A prática ilícita da venda e consumo de drogas na rua São Francisco historicamente é a "forma social" que domina na região, constituindo-se um passado objetivado que permaneceu nas formas sociais e geográficas atuais (SANTOS, 2012), mesmo com as mudanças estruturais advindas da revitalização do local.

$\mathrm{Na}$ tentativa de conter esse tipo de uso da rua e da praça, verificou-se a presença de policiamento e constantes abordagens (Figura 11). Conforme registro em diário de campo:

Às 15h26 um carro da Guarda Municipal que passa pela rua Presidente Faria reduz a velocidade, observa a praça e segue caminho. Às $15 \mathrm{~h} 29$ a Guarda Municipal aparece e manda o pessoal que está sentado no banco do fundo da praça virar para o muro, pôr a mão na cabeça e ficar em silêncio. [...] O policial revista as mochilas. [...] Às $15 \mathrm{~h} 43$ os Guardas liberam os jovens, que vão embora da praça (Diário de Campo, 12/08/2015).

10 Proposto no Plano de Governo Municipal 2009/2012, este projeto surgiu a partir da percepção de urbanistas e gestores públicos da necessidade de revitalização da área central da cidade compreendendo, dentre outras questões, a readequação de uso e ocupação da área (IPPUC, 2012, grifo nosso). 
Figura 11 - Abordagem policial na PBC - dia de semana/tarde

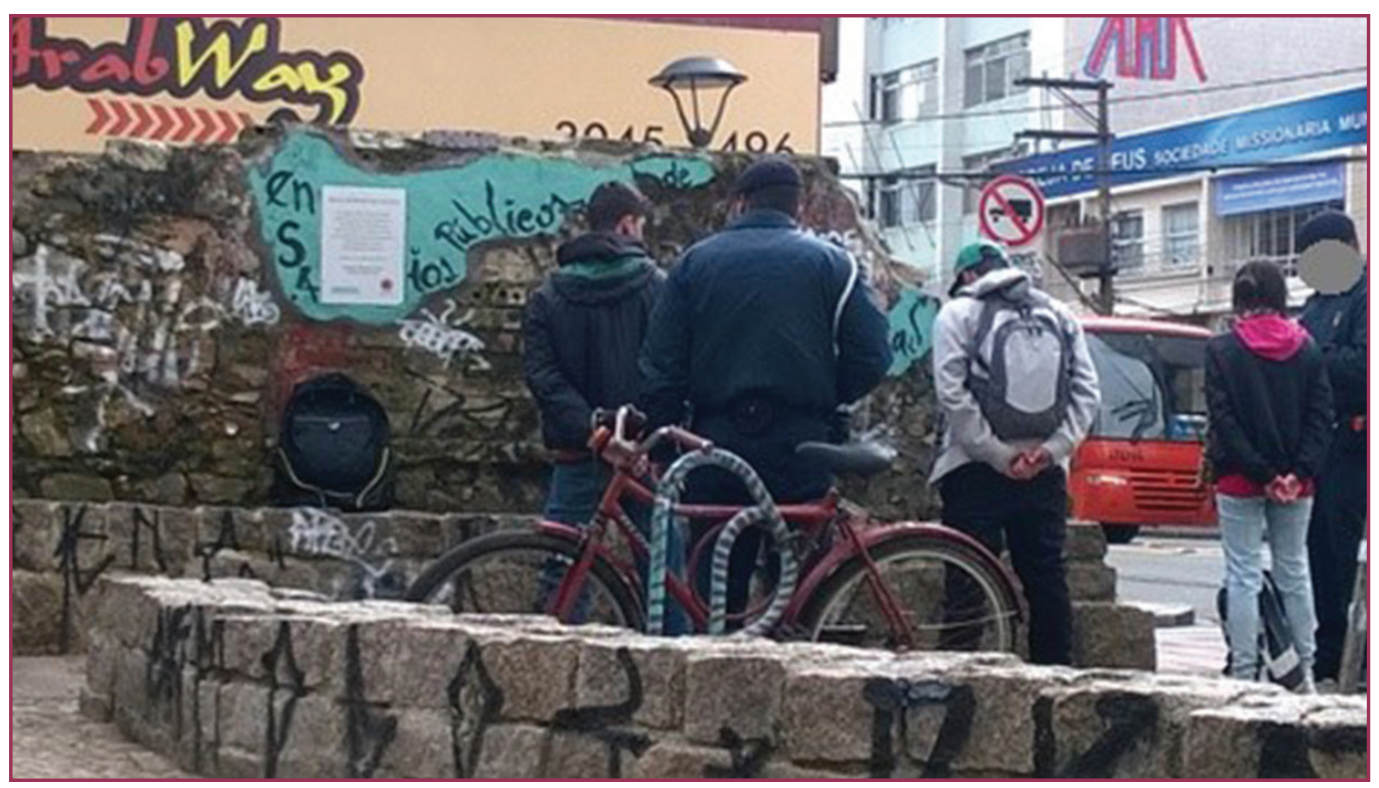

Fonte: Arquivo pessoal (2015)

Morente (2018, p. 08) afirma que "la presión neoliberalista ejercida sobre el espacio público expulsa lo público de este, distinguiendo entre los usos supuestamente 'correctos' de los supuestamente 'incorrectos' o 'malos' (Iveson, 1998) [...]'.

O consumo do álcool é legalizado, mas sabe-se que o plantio, venda e consumo de drogas é proibido por lei (BRASIL, 1938). Segundo Certeau (2014, p. 210), "[...] seja como for, sempre é verdade que a lei se escreve sobre os corpos" e, no caso da praça, as abordagens policiais consistiam no método mais recorrente utilizado para impedir a ocorrência desta prática no local.

Com relação aos usuários da praça, evidenciou-se que um público diferente daquele envolvido no seu processo de construção vem utilizando o local. A PBC tem em sua natureza uma relação estreita com a comunidade ciclista. No entanto, em nenhum momento sua utilização restringiu-se apenas a este público específico. Verifica-se que houve uma transição no perfil dos usuários, quando considerando o momento da construção e após sua inauguração.

\begin{abstract}
A nossa ideia era que fosse ocupada pelo público em geral, não dá pra prever quem vai estar ali. Então eu acho que é parte da construção de um processo em que as pessoas ainda não têm esse discernimento de que o espaço público é um espaço delas, pra ser cuidado, então é uma questão de educação, que é um trabalho a ser realizado. [...] Interessante ver isso, porque às vezes você planeja alguma coisa e ela começa a se transformar em uma coisa diferente, eu não acho que isso é ruim, a gente tem que entender assim, a nossa média de faixa etária, do pessoal que trabalhou ali, é de entre 25 acho até uns $40 \mathrm{e}$ poucos anos, [...] o pessoal que está usando ali são adolescentes, é outra geração, talvez a gente não entenda a necessidade deles ou a maneira deles de se divertirem, mas, tão ali, tão usando... (INTEGRANTE DE ASSOCIAÇÃO DE CICLISTAS 3, grifo nosso).
\end{abstract}

A apropriação de um local, especialmente um espaço público, nem sempre acontece de modo harmonioso e pode estar permeada por conflitos, devido à diversidade de interesses e usos, dinamicidade e complexidade sociais. Para Santos (2012, p. 94) existe uma inseparabilidade entre os objetos e as ações, mas as ações por sua vez redefinem os objetos, afirmando que "[...] os resultados da ação humana não dependem unicamente da racionalidade da decisão e da execução. Há, sempre, uma cota de imponderabilidade no resultado, devida, de um lado, à 
natureza humana e, de outro, ao caráter humano do meio" (SANTOS, 2012, p. 94). Além disso, para Lefebvre (2001, p. 22) "[...] a vida urbana pressupõe encontros, confrontos das diferenças, conhecimentos e reconhecimentos recíprocos (inclusive no confronto ideológico e político) dos modos de viver, dos 'padrões' que coexistem na cidade". Morente (2018), sustentada por diversos autores, também aponta que no espaço público,

[...] cuya esencia es la alteridad, la consistência es tanto más natural, cuanto más frágil y precaria; no sólo existe la necesidad manifiesta de pluralidade y divergencia, sino también la de enmarañamiento y anquilosamiento (Goffman, 1963; Duque, 2011; Estévez Villarino, 2012). La fluidez masiva, las digressiones incidentales -confluencia/dispersión-, la profusión de lo inesperado y la precariedad de los vínculos 0 la ausencia de reciprocidad, caracterizan la turbulenta interacción en este escenario circunstancial (MORENTE, 2018, p. 9).

De um modo geral, a população que mais se apropria da praça é constituída por jovens e adultos e mais intensamente no período da noite e nos finais de semana, no entanto, percebese a necessidade de políticas e ações que possam promover um sentimento de pertencimento que possibilite aproximar mais efetivamente a comunidade do entorno com o local.

Quase um ano após a inauguração da PBC, uma oficina de mosaicos realizada pela escola próxima ocorreu neste sentido. Uma voluntária que participou da construção da praça foi convidada para ministrar esta oficina, cujos mosaicos produzidos foram instalados pelos alunos no muro histórico da praça (Figura 12). Um elemento construído pelos alunos e que compõe a paisagem da praça, local frequentado por muitos alunos, poderia ser um meio de potencializar os significados daquele espaço. Segundo a Voluntária 1

[... era semana cultural da escola e a professora falou assim "Ah, ia ser muito bacana se os alunos se sentissem também responsáveis e copartícipes da praça, né, fizessem também alguma coisa, sentissem que também eles são donos, que também eles fizeram, ajudaram de alguma forma". Eu falei "Nossa, tudo a ver, eu acho que eles usam ali, a escola é bem em frente e, eu, se quiser, vamos fazer uma oficina de mosaico", depois vamos fazer, colocar o mosaico no muro, que fica bem em frente mesmo da escola (VOLUNTÁRIA 1).

Figura 12 - Construção do mosaico no muro histórico da PBC

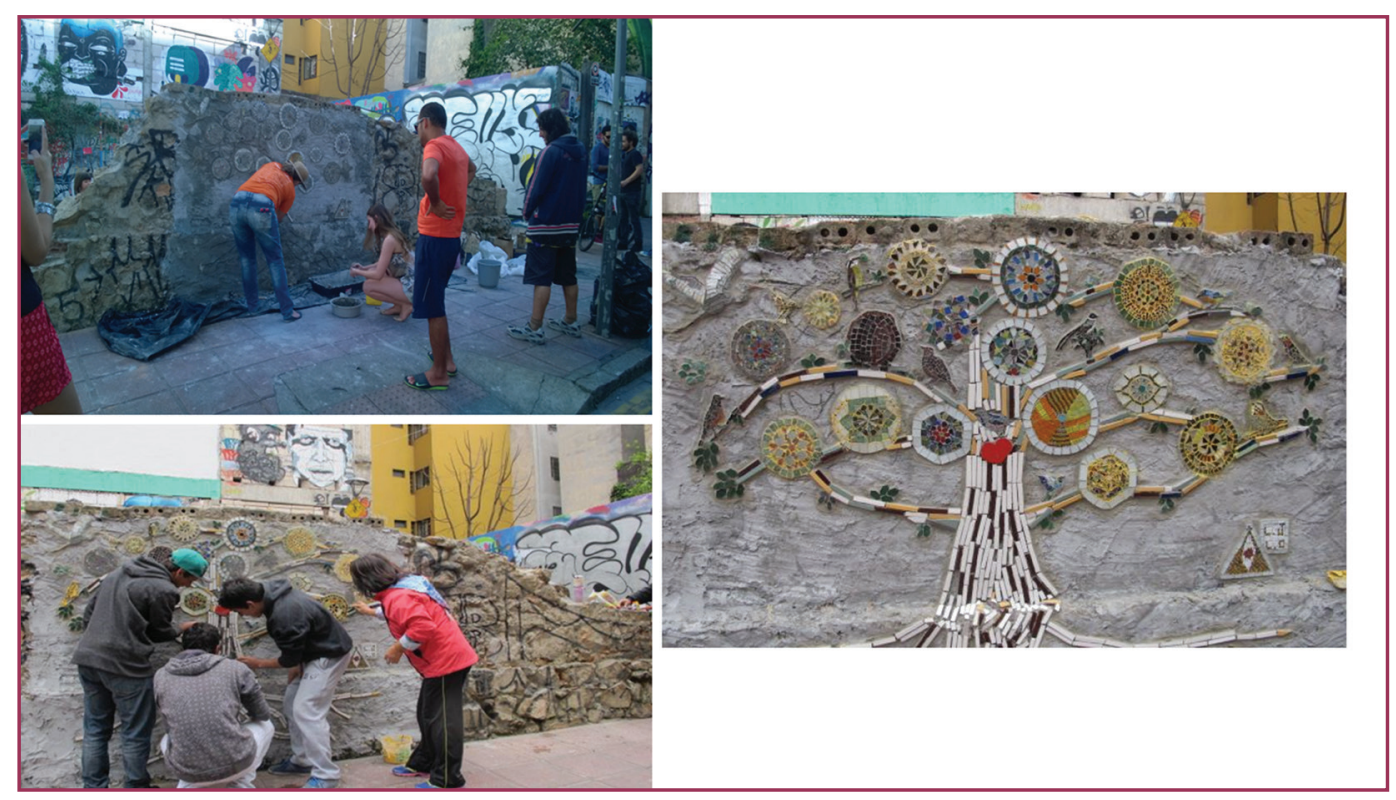

Fonte: Arquivo pessoal (2015) / Leda EmiSew - Rede Social (2015) 
Verificou-se que as pessoas que se envolveram de alguma forma com a implementação da PBC tendem a não ser indiferentes e algumas pequenas intervenções, frequentemente relacionadas à manutenção do espaço e equipamentos, continuam sendo realizadas e vêm sendo protagonizadas justamente por voluntários que auxiliaram nos mutirões.

\section{CONSIDERAÇÕES FINAIS}

O movimento de construção da PBC constituiu-se um processo singular que contou com a participação de diferentes atores sociais e que resultou na materialização de um espaço de lazer no centro de Curitiba.

Mesmo que a implementação da PBC tenha sido protagonizada principalmente por ciclistas de várias regiões da cidade, nota-se que aqueles que a idealizaram não são necessariamente (ou exclusivamente) os que dela usufruem no cotidiano. Mesmo que a bicicleta tenha sido o elemento central na criação do espaço e que ações relacionadas ao seu uso na cidade tenham a praça como ponto de referência, percebeu-se que a utilização da PBC tende a extrapolar a relação com esse modal. Ao longo do processo e após sua concretização, pessoas com diferentes perfis e interesses se apropriaram do local, observando-se 0 uso da praça também com outras finalidades, como escutar música, manusear o celular, fumar, beber, se reunir com os amigos.

Espaço prioritariamente de circulação durante o dia, a PBC tende a se transformar, especialmente nos finais de semana, em um local de vida noturna intensa. Nem todos os "lazeres" são considerados lícitos ou praticados de forma unânime, e tensões decorrentes da apropriação rápida do espaço foram verificadas. 0 espaço público possibilita que diferentes culturas, hábitos e experiências de vida convivam, ressaltando essa diversidade e, como consequência, a convivência pode acontecer de forma harmoniosa, mas também permeada por conflitos ou embates, como no caso estudado.

A apropriação da PBC vem acontecendo e iniciou pela transformação física de um espaço anteriormente subutilizado e prosseguiu pela identificação simbólica proporcionada pelas interações que promove. Mesmo com todas as controvérsias relacionadas às diferentes e, por vezes, simultâneas formas de uso, a PBC tornou-se símbolo imaterial e espaço do "ativismo gentil" (COOMBS, 2012) pela causa da bicicleta na cidade, em busca da transformação da sociedade por meio da ação, forçando vínculos, contatos e aprendizados constantes relacionados à convivência com o diferente e à consciência do exercício dos direitos e deveres do cidadão, tendo como base atividades vivenciadas no âmbito do lazer. Neste sentido, compreender a conexão entre cidade, lazer e cidadania, como possibilidade de espaço de formação de sujeitos emancipados e autônomos, requer compreendê-la como um direito a ser conquistado. Isso implica necessariamente lutar pela convivência coletiva no espaço público, pois, "[...] cada lugar é, ao mesmo tempo objeto de uma razão global e de uma razão social, convivendo dialeticamente" (SANTOS, 1996, p. 273). 


\section{REFERÊNCIAS}

ANÍBAL, Felipe; ANDRADE, Marcelo. "Longe do agito da noite, outra São Francisco". Gazeta do Povo, Curitiba, 27 de setembro de 2015. Disponível em: http://www.gazetadopovo.com.br/vida-ecidadania/longe-do-agito-da-noite-outra-sao-francisco-9zrk82851mkxiquwzi2uqrhnq. Acesso em: 15 jan. 2016.

ANÍBAL, Felipe; ANDRADE, Marcelo. "A rua com vocação para a boemia e para a polêmica". Gazeta do Povo, Curitiba, 29 de Setembro de 2015b. Disponível em: http://www.gazetadopovo. com.br/vida-e-cidadania/prefeitura-aposta-em-arte-e-cultura-para-reordenar-a-ocupacaocihq2wcafrz8uqwn6rizp9qna. Acesso em: 15 jan. 2016.

BICICLETADA CURITIBA. Disponível em: https://www.facebook.com/pg/bicicletadacuritiba/ about/?ref=page internal. Acesso em: 9 nov. 2018.

BRASIL. Conselho Nacional de Saúde. Resolução n. 466, de 12 de dezembro de 2012. Diário Oficial da União, Poder Legislativo, Brasília, DF, 13 jun. 2013. Disponível em: http://www. planalto.gov.br/ccivil/Decreto-Lei/1965-1988/Del0464.htm Acesso em: 14 dez. 2016.

BRASIL. Conselho Nacional de Saúde. Decreto-lei no 891, de 25 de novembro de 1938. Aprova a Lei de Fiscalização de Entorpecentes. Disponível em: http://www.planalto.gov.br/ ccivil 03/decreto-lei/1937-1946/Del0891.htm. Acesso em: 20 dez. 2017.

CAVALCANTE, Sylvia; ELIAS, Terezinha Façanha. Apropriação. In: CAVALCANTE, Sylvia; ELALI, Gleici Azambuja. (orgs.). Temas básicos em psicologia ambiental. Petrópolis: Vozes, 2011. p. 63-69.

CERTEAU, Michel de. A invenção do cotidiano: Artes de fazer. 22 ed. Petrópolis: Vozes, 2014. v.1.

CICLOIGUAÇU. Associação de Ciclistas do Alto Iguaçu. Apresentação. Disponível em: https:// cicloiguacu.org.br/a-cicloiguacu/apresentacao/. Acesso em: 12 abr. 2019.

COOMBS, Gretchen. Park(ing) day. Contexts, v. 11, n.3, p. 64-65, 2012. Disponível em: http:// contexts.sagepub.com. DOI 10.1177/1536504212456186. Acesso em: 9 nov. 2018

IMOVELWEB. ImovelWeb Index - Relatório de mercado Curitiba. jan. 2019. Disponível em: http://produto.imovelweb.com.br/2018/index/INDEX-CB-RELATORIO-2019-01.pdf. Acesso em: 11 abr. 2019.

INSTITUTO LEGADO. Bicicletaria Cultural. Disponível em: https://institutolegado.org/organizacao/ bicicletaria-cultural/. Acesso em: 9 nov. 2018.

IPPUC. Instituto de Pesquisa e Planejamento Urbano de Curitiba. Revitalização Rua São Francisco (Cartilha). Prefeitura Municipal de Curitiba. 2012.

LEFEBVRE, Henry. 0 direito à cidade. São Paulo: Centauro, 2001.

MENDONÇA, Eneida Maria Souza. Apropriações do espaço público: alguns conceitos. Estudos e Pesquisas em Psicologia, v. 7, n. 2, p. 296-306, ago. 2007.

MINAYO, Maria Cecília de Souza. Análise qualitativa: teoria, passos e fidedignidade. Ciência \& Saúde Coletiva, v.17, n.3, 621-626, mar. 2012. 
MORENTE, Fran. De la acumulación a la apropiación: una reflexión acerca del espacio público en la ciudad contemporánea. Urbe. Revista Brasileira de Gestão Urbana, v.10, n. 3, p. 650662, set./dez. 2018,

RECHIA, Simone. Cidadania e o direito ao lazer nas cidades brasileiras: da fábula à realidade. In: GOMES, Christianne Luce; FERREIRA, Hélder Isayama. O Direito social ao lazer no Brasil. Campinas: Autores Associados, 2015.

SANTANA, Daniella. Tschöke. Praça de Bolso do Ciclista de Curitiba/PR: idealização, cotidiano e o uso da bicicleta como forma de contestação. 2016. 185f. Dissertação (Mestrado em Educação Física) - Setor de Ciências Biológicas, Universidade Federal do Paraná, Curitiba, 2016.

SANTANA, Daniella Tschöke; RECHIA, Simone; RODRIGUES, Emília Amélia Pinto Costa. As brechas da cidade: a Praça de Bolso do Ciclista da cidade de Curitiba/Paraná. Movimento, Porto Alegre, v. 23, n. 1, p. 311-324, jan./mar. de 2017.

SANTOS, Milton. A Natureza do espaço. 5.ed. São Paulo, EDUSP, 2012.

SANTOS, Milton. Pensando o Espaço do Homem. 5.ed. São Paulo, EDUSP, 2012b.

SANTOS, Milton. A natureza do espaço: técnica e tempo, razão e emoção. São Paulo: Hucitec, 1996.

SOLÀ-MORALES, Ignasi de. Urbanité intersticielle. Inter Art Actuel, n. 61, p.27-28, 1995.

SOUZA, Marcelo Lopes. Os conceitos fundamentais da pesquisa sócio-espacial. Rio de Janeiro: Bertrand Brasil, 2013.

YIN, Robert. Estudo de caso: planejamento e métodos. 2. ed. Porto Alegre: Bookman, 2001.

\section{Apoio:}

Coordenação de Aperfeiçoamento de Pessoal de Nível Superior - Brasil (CAPES) - Código de Financiamento 001. 